\title{
Faktor Risiko Kematian Neonatus dengan Penyakit Membran Hialin
}

Alifah Anggraini, Sumadiono, Setya Wandita

Bagian Ilmu Kesehatan Anak Fakultas Kedokteran Universitas Gadjah Mada - RSUP Dr. Sardjito, Yogyakarta

Latar belakang. Angka kematian bayi (AKB) menurut Survei Demografi dan Kesehatan Indonesia (SDKI) pada tahun 2002-2003 adalah 35 per 1000 kelahiran hidup. Dua pertiga kematian bayi merupakan kematian neonatal dan disebabkan terutama oleh persalinan prematur. Penyakit membran hialin (PMH) merupakan penyebab terbanyak dari angka kesakitan dan kematian pada bayi prematur.

Tujuan. Mengetahui faktor-faktor risiko yang memengaruhi kematian pasien PMH yang dirawat di Instalasi Maternal Perinatal RSUP Dr. Sardjito.

Metode. Rancangan penelitian yang digunakan adalah kasus-kontrol berdasarkan data sekunder dari data dasar neonatus dan catatan medik pasien bayi baru lahir yang dirawat dan didiagnosis PMH di RSUP Dr.Sardjito, Yogyakarta selama tahun 2007 - 2011.

Hasil. Proporsi kematian neonatus dengan penyakit membran hialin di RSUP Dr. Sardjito selama 2007 - Oktober 2011 adalah 52\%. Faktor risiko kematian neonatus dengan penyakit membran hialin yang bermakna secara statistik adalah asfiksia dengan OR 4,97 (IK 95\% 2,39-10,28). Analisis dengan metode regresi logistik menunjukkan bahwa asfiksia merupakan faktor risiko independen kematian neonatus dengan penyakit membran hialin (aOR 5,15, IK 95\% 2,43-10,91).

Kesimpulan. Asfiksia merupakan faktor risiko independen kematian neonatus dengan penyakit membran hialin. Penanganan asfiksia dengan resusitasi yang tepat diperlukan untuk menurunkan risiko kematian neonatus dengan penyakit membran hialin. Sari Pediatri 2013;15(2):75-80.

Kata kunci: penyakit hialin membran, kematian, faktor risiko

ingkat kematian bayi di Indonesia masih tergolong tinggi jika dibandingkan dengan negara-negara anggota ASEAN. Angka kematian bayi (AKB) menurut Survei

\footnotetext{
Alamat korespondensi:

Dr. Alifah Anggraini, Bagian Ilmu Kesehatan Anak, Fakultas Kedokteran Universitas Gadjah Mada/RSUP. Dr. Sardjito, Jalan Kesehatan No. 1 Sekip Yogyakarta 55284, Indonesia. Telp. (0274) 561616, (0274) 583745. E-mail: dr_alifah_a@yahoo.co.id
}

Demografi dan Kesehatan Indonesia (SDKI) pada tahun 2002-2003 adalah 35 per 1000 kelahiran hidup. Dua pertiga kematian bayi merupakan kematian neonatal. ${ }^{1}$

Persalinan prematur merupakan penyebab utama kematian neonatal dini dan memberikan kontribusi lebih dari $70 \%$ penyebab kematian perinatal pada bayi tanpa kelainan bawaan. Pada bayi kurang bulan (prematur) sering timbul penyulit yang berhubungan dengan kekurang-matangan organ. ${ }^{2}$ 
Alifah Anggraini dkk: Faktor risiko kematian neonatus dengan penyakit membran hialin

Penyakit membran hialin (PMH) merupakan penyebab terbanyak angka kesakitan dan kematian pada bayi prematur. Di Amerika Serikat, PMH didapatkan pada sekitar 10\% dari seluruh bayi prematur. $^{3}$ Angka kematian PMH di Amerika Serikat adalah 21,3 per $100.000 .{ }^{4}$

Selain berhubungan dengan usia kehamilan, angka kejadian PMH juga berhubungan dengan berat badan lahir. ${ }^{5}$ Lima puluh sampai enam puluh persen bayi yang lahir kurang dari usia kehamilan 29 minggu menderita $\mathrm{PMH}$, dan 44\% kasus didapatkan pada bayi dengan

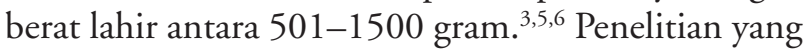
dilakukan Wardhani $\mathrm{dkk}^{7}$ menyebutkan bahwa PMH meningkatkan risiko kematian bayi dengan berat lahir 1000-<2500 gram yang dirujuk ke RSUP Dr. Sardjito Yogyakarta (OR: 3,98, IK 95\% 1,439 - 10,613).

Upaya untuk menurunkan kematian neonatal merupakan kunci utama dalam keberhasilan penurunan kematian bayi. Salah satu target dari Millenium Development Goals (MDGs) adalah menurunkan angka kematian balita (AKBA) sebesar dua-pertiganya dalam kurun waktu 1990-2015. ${ }^{1}$ Untuk mendukung terlaksananya $M D G$ s perlu dilakukan penelitian mengenai faktor-faktor yang berperan dalam kematian neonatus agar dapat dikembangkan upaya pencegahan dan tata laksana yang sesuai.

Penyakit membran hialin (PMH) merupakan target terbanyak pengembangan terapi dan teknologi perawatan intensif neonatus. Sebelum tahun 1950 belum ada intervensi spesifik untuk PMH. Oksigen mulai digunakan dalam intervensi $\mathrm{PMH}$ pada tahun 1950-1960, dan setelah tahun 1990 intervensi spesifik untuk PMH mulai dengan kortikosteroid antenatal, surfaktan, dan teknologi perawatan lanjut, seperti high-frequency oscillation dan extracorporeal membrane oxygenation. ${ }^{8}$

Data mengenai penyebab angka kematian bayi yang tinggi dengan $\mathrm{PMH}$ di negara berkembang sangat terbatas. ${ }^{9}$ Penelitian yang dilakukan Fidanovski $\mathrm{dkk}^{9}$ mendapatkan bahwa faktor risiko kematian bayi dengan PMH yang menggunakan ventilasi mekanik adalah air-leak syndrome, berat badan lahir $\leq 1,5 \mathrm{~kg}$, dan bronchopulmonary dysplasia (BPD). Penelitian lain yang serupa menunjukkan bahwa usia kehamilan $<30$ minggu, presentasi bokong dan skor APGAR 5 menit $\leq 7$ merupakan faktor risiko kematian bayi PMH. ${ }^{10}$ Bhutta dan Yusuf ${ }^{11}$ mendapatkan hasil yang serupa bahwa skor APGAR menit pertama yang rendah merupakan salah satu faktor risiko kematian bayi dengan $\mathrm{PMH}$.
Tujuan penelitian ini adalah mengetahui faktorfaktor risiko yang mempengaruhi kematian pasien PMH yang dirawat di Instalasi Maternal Perinatal RSUP Dr. Sardjito dan menilai besarnya kontribusi masing-masing faktor tersebut.

\section{Metode}

Penelitian rancang bangun kasus-kontrol berdasarkan data sekunder dari data dasar neonatus dan catatan medik pasien instalasi maternal dan perinatologi RSUP Dr.Sardjito, Yogyakarta, selama lima tahun (2007-2011). Kriteria inklusi kelompok kasus meliputi bayi baru lahir yang didiagnosis menderita PMH, usia kehamilan $<37$ minggu, dan meninggal pada umur neonatal (0-28 hari). Kriteria inklusi kelompok kontrol meliputi bayi baru lahir yang didiagnosis menderita PMH, usia kehamilan <37 minggu, dan hidup sampai dengan umur 28 hari. Subyek penelitian tidak diikutsertakan dalam penelitian jika terdapat kelainan kongenital mayor, mengalami distres napas karena pneumonia, sindrom aspirasi mekoneum atau pneumotoraks; pasien pulang paksa, dan tidak mempunyai data lengkap yang dibutuhkan pada penelitian ini.

Faktor risiko kematian neonatus dengan $\mathrm{PMH}$ yang dinilai adalah terapi pengganti surfaktan, duktus arteriosus persisten, sepsis, kecil masa kehamilan, dan asfiksia. Data penelitian dianalisis menggunakan program SPSS for windows dan untuk analisis perbandingan antara kedua kelompok menggunakan chi-square dengan $\mathrm{p}<0,05$ ditetapkan sebagai kemaknaan statistik. Untuk menilai variabel yang berpengaruh terhadap kematian neonatus dengan PMH dilakukan analisis regresi logistik.

\section{Hasil}

Sebanyak 172 kasus penyakit membran hialin (PMH) didapatkan dari data dasar neonatus instalasi maternal perinatal RSUP Dr. Sardjito selama 2007 - Oktober 2011. Sepuluh kasus dieksklusi karena pasien pulang atas permintaan sendiri, 7 didapatkan kelainan kongenital, dan 12 data tidak lengkap. Setelah dieksklusi, diambil 70 pasien sebagai kelompok kasus dan 70 pasien sebagai kelompok kontrol sesuai perhitungan besar sampel. 
Alifah Anggraini dkk: Faktor risiko kematian neonatus dengan penyakit membran hialin

Tabel 1. Karakteristik dasar subyek penelitian

\begin{tabular}{lcc}
\hline Karakteristik & Meninggal $(\mathrm{n}=70)$ & Hidup $(\mathrm{n}=70)$ \\
\hline Jenis kelamin (n,\%) & $33(47,1)$ & $38(54,3)$ \\
$\quad$ Laki-laki & $37(52,9)$ & $32(45,7)$ \\
$\quad$ Perempuan & & \\
Usa kehamilan (minggu, $\mathrm{n}, \%)$ & $50(71,4)$ & $44(62,9)$ \\
$\quad<32$ & $20(28,6)$ & $26(37,1)$ \\
$\quad \geq 32$ & & \\
Berat badan lahir (gram, n,\%) & $61(87,1)$ & $53(75,7)$ \\
$\quad<1500$ & $9(12,9)$ & $17(24,3)$ \\
$\quad \geq 1500$ & $26(37,1)$ & $44(62,9)$ \\
Cara persalinan (n,\%) & $44(62,9)$ & $26(37,1)$ \\
$\quad$ Operasi Caesar & & \\
$\quad$ Per vaginam & $58(82,9)$ & $61(87,1)$ \\
Jumlah janin(n,\%) & $12(17,1)$ & $9(12,9)$ \\
$\quad$ Tunggal & $5(7,1)$ & $6(8,6)$ \\
$\quad$ Ganda &
\end{tabular}

Tabel 2. Faktor risiko kematian neonatus dengan penyakit membran hialin

\begin{tabular}{lcccc}
\hline Faktor & Meninggal $(\mathrm{n}=70)$ & Hidup $(\mathrm{n}=70)$ & OR $(\mathrm{IK} 95 \%)$ & $\mathrm{p}$ \\
\hline Asfiksia (n,\%) & $43 / 61,4$ & $17 / 24,3$ & $4,97(2,39-10,28)$ & 0,01 \\
KMK (n,\%) & $7 / 10$ & $9 / 12,9$ & $0,75(0,26-2,15)$ & 0,79 \\
Sepsis (n,\%) & $55 / 78,6$ & $58 / 82,9$ & $0,76(0,33-1,76)$ & 0,67 \\
DAP (n,\%) & $5 / 7,1$ & $4 / 5,7$ & $1,27(0,33-4,94)$ & 1,00 \\
Terapi surfaktan (n,\%) & $19 / 27.1$ & $14 / 20$ & $1,49(0,67-3,28)$ & 0,42 \\
\hline
\end{tabular}

KMK: Kecil masa kehamilan; DAP: Duktus arteriosus paten; OR: Odds ratio; IK: Interval kepercayaan

Analisis dilakukan pada sub kelompok usia kehamilan $<32$ minggu, sub kelompok berat badan lahir sangat rendah (<1500 gram) dan sub kelompok bayi dengan persalinan operasi Caesar. Asfiksia merupakan faktor risiko kematian neonatus dengan penyakit membran hialin pada ketiga sub kelompok tersebut; dengan OR 4,00 (IK 95\% 1,67-9,57) pada sub kelompok usia kehamilan <32 minggu, aOR 3,82 (IK 95\% 1,75-8,35) pada sub kelompok berat badan lahir sangat rendah (<1500 gram), dan aOR 24,99 (IK 95\% 5.98-104.43) pada sub kelompok bayi dengan persalinan operasi Caesar.

\section{Pembahasan}

Proporsi kematian neonatus dengan penyakit membran hialin di RSUP Dr. Sardjito selama 2007 - Oktober 2011 adalah 52\%. Hasil tersebut hampir sama dengan penelitian di Spanyol yang mendapatkan hasil $41,5 \%{ }^{12}$ dan di India mencapai 50\%-75\% ${ }^{13}$.

Berdasarkan karakteristik subyek penelitian terdapat perbedaan antara kedua kelompok untuk cara persalinan. Kematian lebih banyak terjadi pada kelompok dengan cara persalinan per vaginam. Penelitian di Amerika Serikat, dibuktikan bahwa persalinan dengan cara operasi Caesar meningkatkan ketahanan hidup (survival) bayi imatur dan menurunkan kematian neonatus. ${ }^{14}$ Begitu pula Lee dan Gould ${ }^{15}$ melaporkan hal yang serupa. Efek proteksi persalinan dengan operasi Caesar diduga berhubungan dengan stres yang berkurang dan trauma janin yang biasa terjadi pada persalinan per vaginam. Stres yang berkurang selama proses persalinan akan memengaruhi respon inflamasi terhadap paparan eksogen berbahaya (seperti infeksi) yang terjadi segera setelah lahir. ${ }^{14}$

Hasil penelitian Deng $\mathrm{dkk}^{16}$ menyatakan bahwa mortalitas pasien penyakit membran hialin meningkat 
secara bermakna dengan adanya asfiksia. Penelitian oleh Fidanovski $\mathrm{dkk}^{9}$ juga menyebutkan bahwa terdapat risiko kematian lebih tinggi pasien penyakit membran hialin dengan skor Apgar 1 menit dan 5 menit yang lebih rendah meskipun skor Apgar 1 menit bukan merupakan faktor risiko kematian yang independen. Penelitian lain juga melaporkan asfiksia merupakan faktor yang meningkatkan mortalitas pasien dengan penyakit membran hialin. ${ }^{11}$

Hubungan asfiksia dengan peningkatan risiko kematian neonatus masih belum jelas. Penelitian pada domba baru lahir yang menderita asfiksia menunjukkan adanya kerusakan alveolus dan pneumosit tipe II; dan hasil yang serupa juga ditunjukkan pada penelitian babi yang terpapar oleh hipoksia. ${ }^{11}$ Asfiksia dan asidosis dapat menurunkan aktivitas enzim yang berperan pada sintesis lesitin dan inaktivasi surfaktan. ${ }^{17}$

Berdasarkan hasil penelitian kami, maka tindakan resusitasi neonatus yang tepat perlu ditingkatkan dalam penanganan asfiksia. Kebijakan penggunaan oksigen pada resusitasi awal bayi prematur dapat menurunkan kematian akibat penyakit membran hialin dari $10,8 \%$ menjadi $6,5 \% .{ }^{18}$ Penelitian lain juga menunjukkan bahwa resusitasi yang adekuat saat lahir dan pencegahan terjadinya stres akibat asfiksia dapat menurunkan kematian akibat penyakit membran hialin. ${ }^{19}$

Faktor risiko lain yang dinilai adalah kecil masa kehamilan (KMK), sepsis, duktus arteriosus paten (DAP) dan terapi surfaktan. Faktor-faktor tersebut tidak terbukti menjadi faktor risiko kematian neonatus dengan PMH. Hasil penelitian kami serupa dengan penelitian oleh Nichpanit ${ }^{10}$ yang mendapatkan kecil masa kehamilan bukan faktor risiko kematian neonatus dengan penyakit membran hialin. Efek protektif KMK terhadap penyakit membran hialin terjadi jika faktor usia kehamilan dikontrol. Penyakit membran hialin lebih jarang terjadi pada bayi dengan KMK karena maturasi paru dipercepat. ${ }^{20}$ Kelemahan penelitian kami adalah tidak memasangkan subyek dengan usia kehamilan yang sama. Selain itu, jumlah subyek penelitian yang menderita kecil masa kehamilan hanya 16 pasien $(22,9 \%)$.

Analisis pada sub kelompok usia kehamilan $\geq 32$ minggu mendapatkan bahwa 75\% bayi KMK hidup. Hal tersebut mencerminkan efek protektif KMK terhadap penyakit membran hialin sesuai teori di atas meskipun secara statistik tidak didapatkan perbedaan bermakna. Ketidakbermaknaan tersebut kemungkinan dipengaruhi oleh jumlah subyek yang kecil. Perlu penelitian lanjutan dengan jumlah subyek bayi KMK yang lebih besar.

Sepsis juga tidak menjadi faktor risiko kematian neonatus dengan penyakit membran hialin. Hal tersebut tidak sesuai dengan hasil penelitian Fidanovski $\mathrm{dkk}^{9}$ yang menyatakan sepsis menurunkan risiko kematian bayi prematur dengan penyakit membran hialin. Penelitian oleh Bry $\mathrm{dkk}^{21}$ tentang paparan fetus terhadap inflamasi dapat merubah maturasi paru ditunjukkan melalui injeksi intra-amniotik IL-1 yang mencetuskan maturasi paru pada fetus kelinci. Injeksi endotoksin juga menginduksi maturasi paru pada fetus sapi. Korioamnionitis merupakan pemicu poten maturasi fetus sapi. ${ }^{22}$ Kelemahan penelitian kami tidak membedakan waktu awitan terjadinya sepsis.

Penelitian yang dilakukan oleh Purba ${ }^{23}$ mendapatkan bahwa kondisi kurang bulan merupakan faktor prediktor mortalitas sepsis neonatorum di RSUP Dr Sardjito. Pada penelitian kami seluruh subyek penelitian berusia <37 minggu (kurang bulan). Sebanyak $64,6 \%$ subyek penelitian yang menderita sepsis lahir pada usia kehamilan $<32$ minggu.

Hasil analisis terhadap faktor duktus arteriosus paten (DAP) dan pemberian surfaktan serupa dengan penelitian Fidanovski $\mathrm{dkk}^{9}$ yang menunjukkan bahwa faktor-faktor tersebut bukan faktor risiko kematian neonatus dengan penyakit membran hialin. Pada penelitian kami jumlah subyek yang menderita DAP 9 bayi. Duapuluh lima persen DAP merupakan komplikasi dari PMH pada bayi dengan berat badan lahir kurang dari 1500 gram $^{24}$ dan kami mendapatkan angka yang lebih besar, yaitu 77,8\%. Penelitian oleh Jones dan Pickering ${ }^{24}$ mendapatkan angka kematian meningkat menjadi $31 \%$ jika didapatkan DAP pada pasien PMH. Angka kematian yang tinggi pada DAP lebih dikarenakan derajat $\mathrm{PMH}$ yang lebih berat bukan efek dari DAP. ${ }^{24}$ Kelemahan penelitian kami adalah tidak membedakan tingkat keparahan PMH.

Faktor lain yang memengaruhi kematian bayi kurang bulan dengan PMH dan DAP adalah adanya pirau besar (large shunt) yang tidak segera diligasi. Durasi pirau besar (large shunt) memengaruhi mortalitas pada bayi PMH dengan DAP yang tergantung alat bantu napas. Semakin cepat ligasi pirau besar semakin rendah angka kematian. ${ }^{25}$ Kelemahan lain penelitian kami adalah diagnosis DAP ditegakkan secara klinis sehingga besarnya pirau tidak dievaluasi.

Penelitian oleh Rojas $\mathrm{dkk}^{26}$ mendapatkan bahwa 
tidak didapatkan perbedaan luaran kematian kelompok yang mendapatkan nasal continuous positive airway pressure (NCPAP) dan terapi surfaktan secara dini dibandingkan kelompok yang hanya mendapat NCPAP saja. Sekitar 20\%-30\% bayi dengan penyakit membran hialin tidak respon terhadap terapi pengganti surfaktan. Beberapa faktor yang berkaitan dengan respon terhadap terapi surfaktan di antaranya imaturitas paru, asfiksia, edema paru, syok, dan infeksi paru. Fujiwara (dikutip dari $\mathrm{Ho}^{27}$ ) melaporkan terdapat $6 \%$ dari pasien yang memiliki respon tidak baik terhadap terapi surfaktan mengalami asfiksia berat. Pada penelitian kami 64,7\% bayi yang mendapat terapi surfaktan dan menderita asfiksia mengalami kematian.

\section{Kesimpulan}

Asfiksia merupakan faktor risiko independen kematian neonatus dengan penyakit membran hialin. Penanganan asfiksia dengan resusitasi yang tepat diperlukan untuk menurunkan risiko kematian neonatus dengan penyakit membran hialin.

\section{Daftar pustaka}

1. Bappenas. Laporan perkembangan pencapaian millennium development goals Indonesia 2007. Jakarta: Kementerian Negara Perencanaan Pembangunan Nasional/Badan Perencanaan Pembangunan Nasional, 2007.

2. Papageorgiou A, Pelausa E, Kovacs L. The extremely low-birth-weight infant. Dalam: MacDonald, MMK Seshia, MD Mullet, penyunting. Avery's neonatology pathophysiology and management of the newborn. Edisi 6. Philadelphia: Lippincott Williams \& Wilkins;2005. h.459-89.

3. American Lung Association (ALA) (2006). Lung disease data at glance: respiratory distress syndrome (RDS). Diunduh dari: http://www.lungusa.org.

4. American Lung Association (ALA) (2008). Lung disease data at glance: Respiratory distress syndrome (RDS). Diunduh dari: http://www.lungusa.org.

5. Gomella TL, Cunningham MD, Eyal FG, Tuttle D. Neonatology: management, procedures, on-call problems, diseases and drugs. New York: McGraw Hill company; 2009.

6. Lemons JA. Very low birth weight outcomes of the
National Institute of Child Health and Human Development Neonatal Research Network, January 1995 through December 1996. Pediatrics 2001;107:e1.

7. Wardhani DM, Wandita S, Haksari EL. Risk factors of neonatal mortality of referred babies with birthweight of 1000 - <2500 grams. Berkala Ilmu Kedokteran 2009;41:143-51.

8. Kamath BD, MacGuire ER, McClure EM, Goldenberg RL, Jobe AH. Neonatal mortality from respiratory distress syndrome: Lessons for low-resource countries. Pediatrics 2011;127:1139.

9. Fidanovski D, Milev V, Sajkovski A, Hristovski A, Kojiv L, Kimovska M [Mortality risk factors in premature infants with respiratory distress syndrome treated by mechanical ventilation]. Srp Arh Celok Lek 2005; 133:29-35.

10. Nichpanit, $S$ Risk factors for death among newborns with respiratory distress syndrome at Kalasin Hospital. Srinagarind Med J 2005;20: 255-61.

11. Bhutta ZA, Yusuf K. Profile and outcome of the respiratory distress syndrome among newborns in Karachi: Risk factors for mortality. J Trop Pediatr 1997;43:143-8.

12. Molina, JJP, Jacobo OB, Valdivia JMR Enfermedad de membrana hialina: mortalidad y factores de riesgo maternos y neonatales. Ginecol Obstet Mex 2006;74:354-9.

13. Kumar A, Bhat BV Respiratory distress in newborn. Indian J Matern Child Health 1996;7:8-10.

14. Malloy, MH Impact of Cesarean section on neonatal mortality rates among very preterm infants in United States, 2000-2003. Pediatrics 2008;122:285-92

15. Lee, HC, Gould JB. Survival advantage associated with cesarean delivery in very low birth weight vertex neonates. Obstet Gynecol 2006;107:97-105.

16. Deng R, Tang BZ, Liu H, Qu Y, My DZ Risk factors on the occurrence and prognosis of neonatal hyaline membrane disease. Sichuan Da Xue Xue Bao Yi Xue Ban 2010;41:688-91 (abstrak).

17. Kenny JD, Adams JM, Corbet AJS, Rudolph AJ The role of acidosis at birth in the development of hyaline membrane disease. Pediatrics 1976;58:184.

18. Omer, MIA, Robson E, Neligan GA. Can initial resuscitation of preterm babies reduce the death rate from hyealine membrane disease?. Arch Dis Child 1974;49:219-21.

19. Robson E, Edmund H. Resuscitation of preterm babies at birth reduces the risk of death from hyaline membrane disease. Arch Dis Child 1982;57:184-6.

20. Zaw, W, Gagnon R, da Silva O. The risks of adverse neonatal outcome among preterm small for gestational age infants according to neonatal versus fetal growth standards. Pediatrics 2003;111:1273. 
21. Bry K, Lappalainen U, Hallman M. Intraamniotic interleukin-1 accelerates surfactant protein synthesis in fetal rabbits and improves lung stability after premature birth. J Clin Invest 1997;99:2992-9.

22. Jobe, AH. Antenatal associations with lung maturation and infection. J Perinatol 2005;25:S31-5.

23. Purba, MA. Faktor prediktor mortalitas sepsis neonatorum awitan dini di RSUP Dr. Sardjito Yogyakarta (Tesis). Yogyakarta: Fakultas Kedokteran Universitas Gadjah Mada, 2011.

24. Jones RWA, Pickering D. Persistent ductus arteriosus complicating the respiratory distress syndrome. Arch Dis Child
1977;52:274-81

25. Clarke DR, Paton BC, Way GL, Stewart JR. Patent ductus arteriosus ligation and respiratory distress syndrome in premature infants. Ann Thorac Surg 1976;22:138-45.

26. Rojas MA, Lozano JM, Rojas MX, Laughon M, Bose CL, Rondon MA, Charry L, dkk. Very early surfactant without mandatory ventilation in premature infants treated with early continuous positive airway pressure: A randomized, controlled trial. Pediatrics 2009; 123:137.

27. Ho, NK. Factors affecting responses of infants with respiratory distress syndrome to exogenous surfactant therapy. Singapore Med J 1993;34: 74-7. 